\title{
The Inhibitory Effect of Endotoxins on Growth of Human Cell Lines
}

\author{
Naoto Yoshinuma, Koji Tanaka, Kuniharu Suzuki, Kenji Fujikawa, \\ Koichi Ito and Seidai Murai
}

(Received 22 February and accepted 10 March 1994)

Key words: endotoxin, subgingival irrigation, Ca9-22 cell, human gingival fibroblast, inhibitory effect

\begin{abstract}
A study was conducted to examine the effect of endotoxin present in periodontal pockets on the proliferation and attachment of human cell lines on the culture plates (Ca9-22 and gingival fibroblasts).

The endotoxin was collected from periodontal pockets of anterior teeth in patients with periodontal disease by subgingival irrigation with sterilized distilled water. The solutions obtained were then subjected to hot phenol-water extraction. The collected endotoxin from periodontal pocket and four other kinds of endotoxin obtained commercially as positive controls were added to cell cultures and the numbers of viable cells on the culture plates were counted.

Among the commercially available endotoxins used in this study, only $500 \mu \mathrm{g} / \mathrm{ml}$ of endotoxin derived from Escherichia coli 0111:B4 significantly decreased the number of attachment cells of Ca9-22 and gingival fibroblasts on the culture plates.

Endotoxin from periodontal pockets at $5 \mu \mathrm{g} / \mathrm{ml}$ also significantly decreased the numbers of attachment cells of both cell lines.
\end{abstract}

\section{Introduction}

The pathological potential of endotoxin derived from Gram-negative bacteria is now well known ${ }^{[1-3]}$. Endotoxin has been implicated in the initiation and progression of periodontal tissue destruction ${ }^{[4-7]}$.

Yoshinuma $^{[8]}$ reported that the solution collected from periodontal pockets by subgingival irrigation contained endotoxin, and that such irrigation decreased the amount of endotoxin in periodontal pockets and improved gingival inflammation.

The purpose of this study was to evaluate the cytotoxicity of endotoxin extracted from periodontal pocket irrigant on two human cell lines (Ca9-22 and gingival fibroblasts).

1. Materials

\section{Materials and Methods}

1) Subjects

The subjects of this study were patients with moderate to severe periodontal disease, who had been referred to Nihon University School of Dentistry.

After a comprehensive periodontal examination, patients showing $\geqq 4 \mathrm{~mm}$ attachment loss at maxillary anterior teeth were selected. Patients with systemic disorders or a history of antibiotic use in the previous 6 months were excluded.

Finally,ten patients, five males and five females, aged 29 to 56 years, were recruited.

吉沼直人, 田中宏司, 鈴木邦治, 藤川謙次, 伊藤公一, 村井正大

Department of Periodontology, Nihon University School of Dentistry

To whom all correspondence should be addressed: Dr. Naoto Yoshinuma, Department of Periodontology, Nihon

University School of Dentistry, 1-8-13 Kanda-Surugadai, Chiyoda-ku, Tokyo 101, JAPAN 


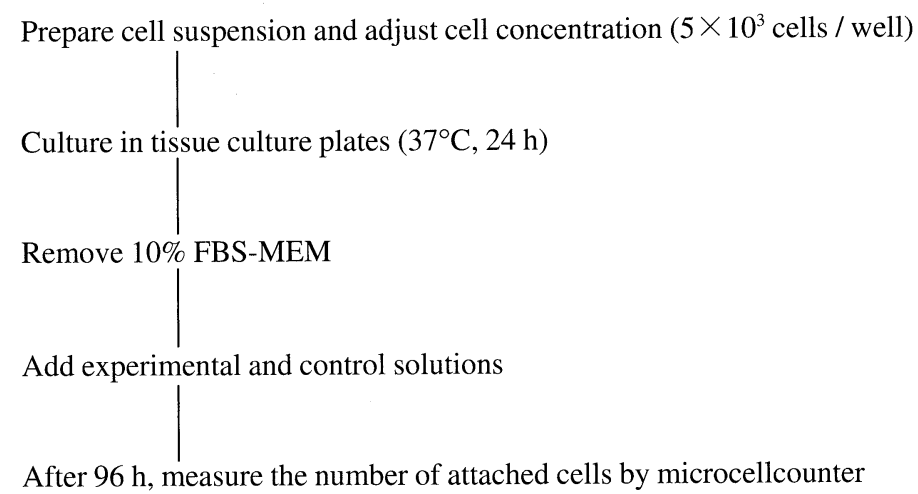

Fig.1 Experimental design

2) Cell lines

Ca9-22 cells, originally derived from human oral carcinoma, were supplied by Tokyo Medical and Dental University. The human gingival fibroblasts employed were derived from an adult patient with a healthy marginal gingiva.

The cells were maintained in $\alpha$-MEM supplemented with $10 \%$ fetal bovine serum and incubated at $37^{\circ} \mathrm{C}$ in $5 \% \mathrm{CO}_{2}$ in an incubator.

3) Commercially available endotoxins

Endotoxin derived from Escherichia coli 0111:B4, Escherichia coli 055:5B, Salmonella typhimurium and Salmonella enteritidis (Difco Labs., U.S.A.) were used.

\section{Methods}

1) Subgingival irrigation

One week after periodontal examination, subgingival irrigation of the periodontal pockets was performed by the method of Hardy et al. ${ }^{[9]}$

Periodontal pockets of anterior teeth were irrigated with sterilized distilled water using a $10 \mathrm{ml}$ disposable syringe fitted with a 1 -inch conical Luer stainless steel $23 \mathrm{G}$ hypodermic needle. The needle was shortened to $2.2 \mathrm{~cm}$ by removing the bevelled end and then bent along its shank to an angle of approximately $130^{\circ}$.

The needle was inserted into the periodontal pocket $3 \mathrm{~mm}$ from the gingival margin. With firm hand pressure, each pocket was then irrigated with $10 \mathrm{ml}$ of distilled water. The irrigation procedure was repeated three times for each tooth.

The irrigants were collected using a funnel held near the maxillary incisor during irrigation. The irrigants from different subjects were stored at $-20^{\circ} \mathrm{C}$ until the next procedure.

2) Extraction of endotoxin

All the samples from the different subjects were pooled and then lyophilized, and the endotoxin was extracted according to the hot phenol-water procedure of Westphal et al. ${ }^{[10]}$

3) Detection of endotoxin

For the Lymlus lysate assay, Pyrodick (Teikoku Zouki, Tokyo, Japan) was used to determine the biological activity of endotoxin in the sample.

After the detection of endotoxin, it was dried and restored at $-20^{\circ} \mathrm{C}$.

4) Inhibitory effect of commercially available endotoxins on cell growth

As a positive control experiment, the inhibitory effect of commercially available endotoxins on human cell growth was investigated. 
The experimental design is shown in Fig. 1. Ca9-22 and gingival fibroblasts suspended in $\alpha$-MEM were inoculated in 96 -well tissue culture plates $\left(5 \times 10^{3}\right.$ cells/well). After $24 \mathrm{~h}$, the commercially available endotoxins were added to the wells at the concentrations of 5, 50 and $500 \mu \mathrm{g} / \mathrm{ml}$ using $\alpha$-MEM. After $96 \mathrm{~h}$, the numbers of cells were counted using a microcellcounter.

5) Inhibitory effect of periodontal endotoxin on cell growth

The experimental design was the same as that used for the commercially available endotoxins. Ca922 and gingival fibroblasts were prepared in tissue culture plates $\left(5 \times 10^{3}\right.$ cells/well).

After $24 \mathrm{~h}$ from inoculation of human cell lines, the concentrations of periodontal endotoxin and endotoxin from E.coli 0111:B4 were adjusted to $5,5 \times 10^{-1}$ and $5 \times 10^{-2} \mu \mathrm{g} / \mathrm{ml}$ in culture medium.

3. Statistical analysis

All statistical evaluations were performed by Student's $t$ test.

\section{Results}

1) Inhibitory effect of commercially available endotoxins on cell growth

Representative results of this study are shown in Tables 1 and 2.

The number of $\mathrm{Ca} 9-22$ cell was $(10.1 \pm 0.8) \times 10^{4}$ cells/well in the negative control, and that at a concentration of $500 \mu \mathrm{g} / \mathrm{ml}$ of endotoxin from E.coli 0111:B 4 was $(6.4 \pm 1.3) \times 10^{4}$ cells/well.

The number of Ca9-22 cells was decreased significantly in comparison with the control at a concentration of $500 \mu \mathrm{g} / \mathrm{ml}$ of endotoxin from E.coli 0111B:4.

The number of gingival fibroblasts was $(21.8 \pm 2.3) \times 10^{4}$ cells/well in the negative control, and that at a concentration of $500 \mu \mathrm{g} / \mathrm{ml}$ of endotoxin from E.coli 0111 :B4 was $(14.4 \pm 3.8) \times 10^{4}$ cells $/$ well. The number of gingival fibroblasts was decreased significantly in comparison with the control at a concentration of $500 \mu \mathrm{g} / \mathrm{ml}$ of endotoxin from E.coli 0111:B4.

2) Inhibitory effect of periodontal endotoxin on cell growth

Represenative results of this experiment are shown in Tables 3 and 4 . The number of Ca9-22 cells was $(8.8 \pm 1.5) \times 10^{4}$ cells/well in the negative control, whereas that at a concentration of $5 \mu \mathrm{g} / \mathrm{ml}$ of periodontal endotoxin was $(5.5 \pm 0.6) \times 10^{4}$ cells/well.

The number of Ca9-22 cells was decreased significantly in comparison with the control at a concentration of $5 \mu \mathrm{g} / \mathrm{ml}$ of periodontal endotoxin.

The number of gingival fibroblasts was $(18.2 \pm 0.8) \times 10^{4}$ cells/well in the negative control, and that at a concentration of $5 \mu \mathrm{g} / \mathrm{ml}$ of periodontal endotoxin was $(10.1 \pm 1.1) \times 10^{4}$ cells/well.

The number of gingival fibroblasts was decreased significantly in comparison with the control at a concentration of $5 \mu \mathrm{g} / \mathrm{ml}$ periodontal endotoxin.

Table 1 Inhibitory effects of the commercially available endotoxins on cell growth of Ca9-22

\begin{tabular}{l|rrrr}
\hline & $500 \mu \mathrm{g} / \mathrm{ml}$ & $50 \mu \mathrm{g} / \mathrm{ml}$ & $5 \mu \mathrm{g} / \mathrm{ml}$ & control \\
\hline E.coli 0111:B4 & $6.4 \pm 1.3$ & $10.1 \pm 1.9$ & $10.2 \pm 2.2$ & $10.1 \pm 0.8$ \\
E.coli 055:5B & $12.4 \pm 1.1$ & $12.3 \pm 0.4$ & $11.3 \pm 1.2$ & \\
S.typhimurium & $12.6 \pm 0.9$ & $13.9 \pm 3.6$ & $13.7 \pm 1.8$ & \\
S.enteritidis & $11.3 \pm 2.8$ & $11.1 \pm 0.3$ & $11.0 \pm 0.9$ & \\
\hline
\end{tabular}

$\left(\right.$ Mean \pm SD) $\times 10^{4}$ cells / well 
Table 2 Inhibitory effects of the commercially available endotoxins on cell growth of gingival fibroblasts

\begin{tabular}{l|cccc}
\hline & $500 \mu \mathrm{g} / \mathrm{ml}$ & $50 \mu \mathrm{g} / \mathrm{ml}$ & $5 \mu \mathrm{g} / \mathrm{ml}$ & control \\
\hline E.coli $0111: \mathrm{B} 4$ & $14.4 \pm 3.8$ & $24.0 \pm 3.8$ & $24.4 \pm 4.8$ & $21.8 \pm 2.3$ \\
E.coli $055: 5 \mathrm{~B}$ & $22.8 \pm 4.0$ & $24.4 \pm 3.8$ & $24.6 \pm 3.4$ & \\
S.typhimurium & $25.0 \pm 1.6$ & $25.0 \pm 2.3$ & $22.4 \pm 1.8$ & \\
S.enteritidis & $23.0 \pm 3.6$ & $22.8 \pm 3.5$ & $23.2 \pm 3.3$ & \\
\hline
\end{tabular}

$($ Mean $\pm \mathrm{SD}) \times 10^{4}$ cells / well

$\mathrm{n}=5$

$\bigcirc: \mathrm{P}<0.01$

Table 3 Inhibitory effect of periodontal endotoxin on cell growth of Ca9-22

\begin{tabular}{l|cccc}
\hline & $5 \mu \mathrm{g} / \mathrm{ml}$ & $5 \times 10^{-1} \mu \mathrm{g} / \mathrm{ml}$ & $5 \times 10^{-2} \mu \mathrm{g} / \mathrm{ml}$ & control \\
\hline E.coli 0111:B4 & $9.1 \pm 1.2$ & $8.1 \pm 0.5$ & $7.9 \pm 0.3$ & \\
P.E. & $5.5 \pm 0.6$ & $7.0 \pm 0.4$ & $7.9 \pm 1.0$ & $8.8 \pm 1.5$ \\
& & & (Mean \pm SD) $\times 10^{4}$ cells $/$ well \\
$\mathrm{n}=5$ \\
\end{tabular}

Table 4 Inhibitory effect of periodontal endotoxin on cell growth of gingival fibroblasts

\begin{tabular}{l|rrrr}
\hline & $5 \mu \mathrm{g} / \mathrm{ml}$ & $5 \times 10^{-1} \mu \mathrm{g} / \mathrm{ml}$ & $5 \times 10^{-2} \mu \mathrm{g} / \mathrm{ml}$ & control \\
\hline E.coli 0111:B4 & $19.0 \pm 1.6$ & $18.6 \pm 0.6$ & $17.4 \pm 0.5$ & \\
P.E. & $10.4 \pm 1.1$ & $16.0 \pm 1.4$ & $17.6 \pm 3.3$ & $18.2 \pm 0.8$ \\
& & & (Mean \pm SD) $\times 10^{4}$ cells $/$ well \\
$n=5$ \\
\end{tabular}

P.E. (Periodontal endotoxin)

\section{Discussion}

It is well known that Gram-negative bacteria are dominant in the subgingival microflora of deep periodontal pocket ${ }^{[11-14]}$. Fine et al. ${ }^{[5]}$ reported that the endotoxin of loosely adherent plaque ${ }^{[15]}$ was more biologically active than that of firmly adherent plaque. Moore et al. ${ }^{[16]}$ demonstrated that $99 \%$ of endotoxin of root surface-associated material on periodontally diseased teeth could be removed by a comparatively gentle procedure. However, few studies have suggested that the endotoxin from periodontal pathogenic bacteria might show cytotoxicity against oral cell lines.

Therefore, we extracted endotoxin from irrigant solution obtained by subgingival irrigation and evaluated its inhibitory effect on human cell growth. Singer et al. ${ }^{[17]}$ reported that inhibition of L-929 cell 
proliferation by endotoxin from E.coli 0127:B13 occurred at a concentration of $100 \mu \mathrm{g} / \mathrm{ml}$. Frank et al. ${ }^{[18]}$ investigated alterations in mitochondria of human gingival fibroblasts upon exposure to medium containing $500 \mu \mathrm{g} / \mathrm{ml}$ of endotoxin from E.coli. Accordingly, we investigated the effects of commercially available endotoxins as a positive control, and found that $500 \mu \mathrm{g} / \mathrm{ml}$ of endotoxin from E.coli 0111:B4 showed the most inhibitory effect on cell growth. Therefore, we employed this endotoxin as a positive control.

Our study demonstrated that the cytotoxicity of endotoxin from periodontal pockets was greater than that of endotoxin from E.coli 0111:B4, and that the number of Ca9-22 and gingival fibroblasts decreased significantly in the presence of concentration of $5 \mu \mathrm{g} / \mathrm{ml}$ endotoxin from periodontal pockets in comparison with the negative control.

Horiba et al. ${ }^{[19]}$ reported that the cytotoxicity of endotoxin from Fusobacterium nucleatum is greater than that of endotoxin from E.coli 0111:B4. Therefore, it is thought that the cytotoxicity of endotoxin from periodontal pockets, as it includes endotoxin of periodontal pathologic bacteria such as F.nucleatum, is greater than that of endotoxin from E.coli 0111:B4. Sugizaki ${ }^{[20]}$ reported that endotoxins prepared from Porphyromonas gingivalis (Bacteroides gingivalis) and Prevotella intermedius (Bacteroides intermedius) at a concentration of $10 \mu \mathrm{g} / \mathrm{ml}$ altered the activity of glucose-6-phosphate dehydrogenase in Gin-1 cell.

Tagata $^{[21]}$ found that the endotoxins from $P$. intermedius and $P$. gingivalis accelerated collagenase activity. Thus it is possible that the endotoxin from periodontal pockets may inhibit cell growth by altering cellular metabolism.

\section{Conclusion}

We extracted endotoxin from periodontal pockets by subgingival irrigation, and evaluated its inhibitory effect on cell growth. It was found that:

1. Among commercially available endotoxins, the numbers of Ca9-22 and gingival fibroblasts were decreased significantly at a concentration of $500 \mu \mathrm{g} / \mathrm{ml}$ of endotoxin from E.coli 0111:B4 in comparison with the control.

2. The numbers of Ca9-22 and gingival fibroblasts were decreased significantly at a concentration of 5 $\mu \mathrm{g} / \mathrm{ml}$ of periodontal endotoxin in comparison with the control.

Therefore, the cytotoxicity of endotoxin from periodontal pockets is greater than that of endotoxin from E.coli 0111:B4.

\section{References}

[1] Newmann, M.G. and Socransky, S.S.: Predominant cultivable microbiota in periodontosis, $J$. Periodont. Res., 12, 120-128, 1977

[2] Slots, J.: The predominant cultivable microflora of advanced periodontosis, Scand. J. Dent. Res., 85, 114-121, 1977

[3] Socransky, S.S.: Microbiology of periodontal disease-present status and future considerations, $J$. Periodontol., 48, 497-504, 1977

[4] Carranza, F.A.: Glickman's Clinical Periodontology, 6th ed., W.B. Saunders Co., Philadelphia, London, Toronto, 368-370, 1984

[5] Fine, D.H., Tabak, L., Oshrain, H., Salkind, A. and Siegel, K.: Studies in plaque pathogenicity. 1. Plaque collection and limulus lysate screening of adherent and loosely adherent plaque, J. Periodont. Res., 13, 17-23, 1978

[6] Isomura, K.: Studies on bacterial endotoxin from Fusobacterium nucleatum-especially the role of endotoxin in periodontal diseases, J. Japan. Ass. Periodont., 27, 328-351, 1985 (in Japanese)

[7] Aleo, J.J., De Renzis, F.A., Farber, P.A.and Varboncoeur, A.P.: The presence and biologic activity of cementum-bound endotoxin, J. Periodontol., 45, 672-675, 1974

[8] Yoshinuma, N.: The determination of endotoxin obtained by subgingival irrigation in periodontal pockets and clinical findings, J. Japan. Ass. Periodont., 30, 375-382, 1988 (in Japanese)

[9] Hardy, J.H., Newman, H.N. and Strahan, J.D.: Direct irrigation and subgingival plaque, J. Clin. 
Periodontol., 9, 57-65, 1982

[10] Westphal, O., Luderritz, O. and Bister, F.: Über die Extraktion von Bakteriene mit Phenol/Wasser, Z. Naturforsh., 76, 148-155, 1952

[11] Slots, J.: Subgingival Microflora and periodontal disease, J. Clin. Periodont., 6, 351-382, 1979

[12] Williams, B.L., Pantalone, R.M. and Sherris, J.C.: Subgingival microflora and adult periodontitis, J. Periodont. Res., 11, 1-18, 1976

[13] Simon, B.I., Goldman, H.M., Ruben, M.P., Broitman, S. and Baker, E.: The role of endotoxin in periodontal disease IV. Bacteriologic analyses of human gingival exudate as related to the quantity of endotoxin and clinical degree of inflammation, J. Periodontol., 43, 468-475, 1972

[14] Shapiro, L., Lodato, F.M., Courant, P.R. and Stallad, R.E.: Endotoxin determinations in gingival inflammation, J. Periodontol., 43, 591-596, 1972

[15] Listgarten, M.A.: Structure of the microbial flora associated with periodontal health and disease in man, J. Periodontol., 47, 1-18, 1976

[16] Moore, J., Wilson, M. and Kieser, J.B.: The distribution of bacterial lipopolysaccharide[endotoxin] in relation to periodontally involved root surfaces, J. Clin. Periodontol., 13, 748-751, 1986

[17] Singer, R.E. and Dutton, W.G.: A Comparison of Effects of endotoxin upon fibroblast proliferation and macromolecular syntheses, J. Dent. Res., 58, 1634-1639, 1979

[18] Frank, A. and Chen, S.Y.: Ultrastructural study of cultured human gingival fibroblasts exposed to endotoxin, J. Periodontol., 53, 86-90, 1983

[19] Horiba, N., Maekawa, Y., Abe, Y., Ito, M., Matsumoto, T., Nakamura, H. and Ozeki, M.: Cytotoxicity against various cell lines of lipopolysaccharides purified from Bacteroides, Fusobacterium and Veillonella isolated from infected root canals, J. Endodon., 15, 530-534, 1989

[20] Sugizaki, K.: Metabolic alternation of Gin-1 fibroblast by lipopolysaccharide from periodontopathic bacteria, J. Japan. Ass. Periodont., 28, 468-483, 1986 (in Japanese)

[21] Tagata, Y.: Effect of endotoxins from periodontopathic bacteria on collagen metabolism of cultured normal human gingival fibroblasts, J. Japan. Ass. Periodont., 31, 755-772, 1989 (in Japanese) 